DOI: https://doi.org/10.31538/ndh.v5i1.590

http://e-journal.ikhac.ac.id/index.php/nidhomulhaq

\title{
KONTRIBUSI BUDAYA, KEPEMIMPINAN, KEPUASAN KERJA, DAN KOMITMEN DALAM PENINGKATAN KINERJA DOSEN
}

\author{
Yusaini \\ Institut Agama Islam Negeri Langsa \\ email: yusaini@iainlangsa.ac.id
}

\begin{abstract}
Abstrak
Penelitian ini mengkaji empat faktor yang diduga berpengaruh secara kausalitas terhadap kinerja dosen di lingkungan Perguruan Tinggi Keagamaan Islam Negeri (PTKIN) di Aceh. Sebingga tujuan penelitian ini ingin mengetabui ada atau tidaknya pengaruh positif budaya organisasi, kepuasan kerja, dan komitmen organisasi terbadap kinerja dosen PTKIN di provinsi Aceh. Populasi dalam penelitian ini adalah selurub dosen PNS di lingkungan PTKIN Aceh berjumlah 727 orang dan ditetapkan sampel dengan rumus Slovin menjadi 258 orang. Instrumen pengumpul data menggunakan kuisioner yang disusun atas 154 pertanyaan yang sebelumnya diuji validitas dan reliabilitas instrumen. Teknik analisis data menggunakan part analisys (analsis jalur) yang sebelumnya disyaratkan ujï persyaratan analisis, seperti uji normalitas, linearitas, homogenitas dan uji korelasi antar variabel. Hasil penelitian ditemukan babwa Budaya organisasi, kepemimpinan, kepuasan kerja dan komitmen organisasi berpengarub langsung terbadap kinerja kerja dosen PTKIN di provinsi Aceh.
\end{abstract}

Kata Kunci: Budaya Organisasi, Kepemimpinan, Kepuasan Kerja, Komitmen Organisasi, Kinerja Dosen

\begin{abstract}
This study examines four factors that allegedly influence causality on the performance of lecturers in the State Islamic Religious College (PTKIN) in Aceh. So the purpose of this study is to find out whether or not there is a positive influence on organizational culture, job satisfaction, and organizational ommitment to the performance of PTKIN lecturers in Aceh province. The population in this study were all PNS lecturers in the PTKIN Aceh environment totaling 727 people and the sample was determined by the Slovin formula to be 258 people. The data collection instrument used a questionnaire composed of 154 questions that were previously tested for the validity and reliability of the instrument. Data analysis techniques used part analysis (path analysis) which was previously required to test requirements for analysis, such as tests of normality, linearity, homogeneity and correlation tests between variables. The results found that organizational culture, leadership, job satisfaction and organizational commitment directly influence the work performance of PTKIN lecturers in Aceh province.
\end{abstract}

Keywords: Organizational culture, Leadership, Job Satisfaction, Organizational Commitment, Work performance

\section{PENDAHULUAN}

Aktivitas dosen dalam menyelesaikan tugas tugasnya di lembaga pendidikan tinggi di Aceh merupakan faktor dominan yang perlu dibahas dan dikaji, dalam upaya peningkatan kinerja.

Salah satu contoh adalah kinerja di perguruan tinggi menjadi basis untuk 
ditingkatkan agar tercapainya tujuan perguruan tinggi Islam di Aceh. Kualitas kerja dosen dapat melalui penyelesaian program kerja pada waktu ditargetkan lembaga. Sehingga, hasil kerja dosen dinilai berkualitas atau sebaliknya adalah terlihat dari hasil pencapaiannya (Yusaini, 2017, p. 3).

Untuk melihat pengaruh setiap variabel yang mempengaruhi kinerja dosen memiliki model yang berbeda oleh setiap ahli. Misalnya, model yang dikembangkan Qolquitt bahwa hasil kerja (kinerja) dan komitmen merupakan variabel outcomes dipengaruhi langsung oleh kepuasan kerja. Sedangkan perilaku kepemimpinan dan budaya lembaga (lembaga) tidak berpengaruh secara langsung terhadap kinerja. Sementara John W. Newstroom menunjukkan satu model bahwa variabel outcomes adalah kinerja dan kepuasan kerja yang merupakan variabel selevel. Padahal pada model Qolquitt, telah dijelaskan kepuasan kerja adalah variabel yang berpengaruh kepada kinerja. Selanjutnya, hasil penelitian Li-Chuan Chu, Ph.D dan Chun-Che Lai menemukan bahwa komitmen lembaga adalah variabel yang mempengaruhi kinerja karyawan, bukan sebagai variabel outcomes. Dari ketiga ahli ini menggambarkan model yang saling kontra antar variabel, baik posisi variabel eksogen maupun endogen. Mereka bertahan pada penemuan teorinya masingmasing. Oleh karena itu, penelitian ini ingin mengubah teori yang bertentangan tersebutu. Dengan demikian artikel ini bermaksud mengkaji empat faktor atau variabel berpengaruh secara kausalitas kepada kinerja dosen di PTKIN Aceh (Yusaini, 2017, p. 16).

\section{KAJIAN LITERATUR}

Kinerja merupakan suatu pengakuan terhadap hasil kerja yang telah diselesaikan dalam target dan waktu tertentu yang terukur secarak efektif dan efisien. Kinerja dapat dipahami sebagai sebuah kualitas dan kuantitas kerja. Ia juga dapat dikatakan sebagai hasil kerja dari suatu pekerjaan, dan juga diartikan dengan nilai suatu pekerjaan dari sejumlah aktivitas karyawan yang bermanfaat, baik secara positif maupun negatif, dalam rangka mencapai tujuan lembaga (Colquitt, J.A, Lipine, 2009).

Budaya perguruan tinggi merupakan suatu sistem yang terjadi dalam aktivitas kerja yang berhubungan dengan nilai dan norma yang secara umum diakui oleh semua pegawai atau orang-orang sebagai anggota perguruan tinggi. Sehingga budaya antara satu perguruan tinggi/lembaga/ organisasi dengan lainnya akan berbeda (Dewi, Harlen, \& Sasmita, 2015). Hal ini memberikan arti bahwa budaya lembaga 
terbentuk berdasarkan norma dan dasar yang sudah diakui secara bersama sepanjang waktu yang telah dilalui dalam bekerja pada sebuah lembaga.

Budaya lembaga dapat dikatakan sebagai Norma, prinsip, nilai, tradisi, dan sistem kerja yang telah biasa dilakukan dan diakui secara bersama dalam aktivitas sehari hari untuk menuntaskan berbagai macam pekerjaan (Adhim \& Hakim, 2019, p. 263). Kebanyakan lembaga, nilai-nilai dan praktik-praktik yang dianut bersama ini telah berkembang pesat seiring dengan perkembangan zaman dan benar-benar mempengaruhi bagaimana sebuah lembaga dijalankan (Robbins, S.P., 2010).

Budaya suatu organisasi atau lembaga tidak terkobstruk dalam waktu singkat. Budaya terbentuk membutuhkan proses dan waktu. Budaya lembaga akan terbentuk sesuai dengan gaya kepemimpinan yang berjalan selama waktu yang telah dilewati oleh semua anggota lembaga atau kelompok sebagaimana yang dirasakan.

Budaya lembaga merupakan segenap asumsi yang dibagi dan diterima secara empiris oleh sekelompok orang dalam bekerja yang sesuai dengan hal yang dirasakan, dipikirkan, dan bereaksi terhadap lingkungan kerja (Kreitner, R., 2014). Budaya lembaga juga dapat diasumsikan sebagai keyakinan bersama yang berkaitan dengan dunia dan tempat mereka bekerja, berkaitan dengan waktu dan ruang, kepribadian manusia, dan hubungan antar manusia (Yulk, 2001)

Oleh karena itu, manfaat urgen dari budaya lembaga (organisasi) adalah membantu untuk memahami lingkungan kerjanya, agar mereka dapat mengurangi kecemasan, ketidakpastian, dan kebingungan dalam bekerja. Dengan demikian ketika menghadapi suatu persoalan dalam bekerja, maka mereka dengan mudah dapat menyelesaikan berdasarkan pengalaman kerja. Keadaan lingkungan kerja yang seperti ini secara alami akan dipahami dan diterima oleh semua anggota bdalam bekerja.

Budaya suatu organisasi merupakan suatu pengakuan yang dirasakan dalam aktivitas kerja yang kemudian dirasakan secara bersama sebagai ciri khas suatu lembaga atau organisasi. Sehingga budaya organisasi dapat artikan sebagai suatu perasaan, asumsi, norma, dan nilai yang diakui bersama dalam suasana kerja (Lunenburg, F.C, 2000).

Permasalahan berikutnya yang berkaitan dengan kinerja adalah kepemimpimpinan. Dimana, pemimpin sudah sangat sering dibicarakan orang di kalangan lembaga, seperti di kalangan karyawan kator, di kalangan lembaga pendidikan, perusahaan dan perguruan tinggi. Banyak yang berkata bahwa 
keberhasilan sebuah lembaga, perusahaan, lembaga dan perguruan tinggi disebabkan oleh keberhasilan pemimpin dalam kepemimpinannya (Hakim, 2018, p. 85). Kepemimpinan dapat dijadikan sebagai kekuatan dalam meningkatkan kehidupan pribadi, sosial, dan profesional mereka dalam suatu kelompok, lembaga atau organisasi (Northouse, 2013).

Kepemimpinan dapat saja dijadikan sebagai suatu perilaku yang kemudian dapat dikaji secara umum dalam rangka memberikan suatu pengetahuan dan keterampilan tentang bagaimana seseorang mampu menerapkan fungsi manajerialnya sesuai dengan program kerja yang direncanakan. Maka keberhasilan pemimpin dapat ditandai dengan roda kepemimpinannya dalam mempengaruhi semua komponen kerja yang bergerak secara kooperatif, sinergi, tepat sasaran dan berhasil meraih semua visi-misi dan tujuan yang diharapkan (Badani, 2014).

Pemimpin merupakan orang yang berhasil mengajak orang lain untuk bekerja untuk memperoleh suatu tujuan bersama. Maka seorang pimpinan harus mampu mempengaruhi kelompok dengan teknik manajerial yang diterapkan agar tercapianya tujuan dan sasaran yang diinginkan (Robbins, 2007).

Kepemimpinan, adalah suatu sistem yang diterapkan dengan suatu metode/perilaku agar dapat mempengaruhi para bawahan untuk dapat bekerja sama secara lebih efektif dan efisien (Hakim, 2016, p. 110).

Tim Dosen Administrasi Pendidikan Universitas Pendidikan Indonesia mendefinisikan kepemimpinan adalah kesanggupan dan keterampilan yang dimiliki pimpinan dalam memmerikan pengaruh, dorongan, tuntunan, arahan, bahkan memaksa orang atau kelompok dalam rangka membantu tercapainya tujuan yang diinginkan (Tim Dosen Administrasi Pendidikan, 2012).

Faktor selanjutnya yang berpengaruh terhadap kinerja adalah kepuasan setelah melakukan pekerjaan, dan hal ini disebuat dengan kepuasan kerja. Kepuasan kerja dikatakan sebagai suatu sikap emosional pada situasi menyenangkan terhadap suatu pekerjaan. Kepuasan kerja dapat dikatakan sebagai suatu perilaku anggota organisasi yang ditampilkan dalam menyelesaikan berbagai pekerjaan (Salangka R, 2015).

Kepuasan kerja adalah suatu respon bersifat emosional yang ditunjukkan oleh anggota lembaga (organisasi) dalam melaksanakan tugas. Seseorang bisa merasa cukup puas pada satu bidang pekerjaannya atau merasa kurang puas terhadap beberapa jenis pekerjaan lainnya (Kreitner, R., 2014). Oleh sebab itu kepuasan harus dapat dibangkitkan atau dihadirkan dalam 
diri seseorang dalam penyelesaian suatu pekerjaan. Sehinngga dampaknya adalah pekerja dalam menyelesaikan pekerjaan berikutnya dengan penuh semangat dan termotivasi.

Kepuasan kerja adalah sikap yang diresponkan dengan sikap positif dengan berbagai tingkatan oleh anggota lembaga organisasi yang berkaitan dengan tugastugas mereka (Bakri, S., 2014).

Kepuasan kerja adalah berhubungan dengan perasaan seseorang yang mencoba membandingkan hasil kinerja yang telah dinyatakan dengan penghargaan yang diterimanya (Baktirani, 2014). Kepuasan kerja yang dikaitkan dalam penelitian ini adalah ungkapan emosional anggota organisasi yang sifatnya menyenangkan atas pekerjaan yang telah dikerjakan. Kepuasan kerja dosen dapat dibentuk oleh kepuasan terhadap gaji yang diterima, kepuasan promosi yang ditawarkan, kepuasan pengawasan yang dilakukan, kepuasan pekerjaan; dan (5) kepuasan terhadap teman kerja.

Faktor berikutnya yang dapat mempengaruhi kinerja adalah Komitmen organisasi. Komitmen berasal dari bahasa latin yaitu: "committere" yang memberikan arti menggabungkan, menyatukan, mempercayai dan mengerjakan. Dengan demikian arti dari menggabungkan identik dengan suatu kelompok yang memiliki keteguhan dalam melaksanakan sesuatu (Situmorang, 2012). Komitmen adalah sikap yang diakui seutuhnya melalui watak yang ditutunjukkan oleh diri seseorang yang terjadi secara alami. Komitmen terjadi melalui sikap realistis, dan tidak mampu membohongi dengan kenyataan yang dialami dan akan dilaksanakan dengan penuh tanggung jawab (Marudut Sianturi, 2012).

Pada dasarnya, komitmen berasal dari respon personal yang yang ada pada diri setiap orang. Sedangkan komitmen secara menyeluruh atau penggabungan seluruh komitmen personal terhadap organisasi dinamakan komitmen organisasi atau lembaga. Komitmen pada suatu organisasi terdi atas tiga sikap, yaitu: mengenal tujuan dari organisasi yang akan dicapai, adanya rasa memiliki terhadap organisasi, dan memiliki loyalitas terhadap organisasi (Gibson. Ivancevich, Donnelly, 2009). Sebaiknya, lembaga mampu memupuk dan mengkondisikan ketiga perasaan tersebut dalam lingkungan kerja. Karena, tiga perasaan ini yang dimiliki oleh setiap karyawan, maka mereka akan sanggup mempertahankan dirinya secara pribadi untuk tetap berada dalam lembaga. Apabila semua anggota lembaga memiliki ketiga perasaan tersebut dalam bekerja, maka komitmen terhadap lembaga sangat tinggi. Lembaga yang memiliki anggota seperti ini 
akan lebih mampu mempercepat roda lembaga dalam menempuh tujuan yang ingin dicapai.

Komitmen organisasi sangat berpengaruh dalam meningkatkan kinerja. Karena komitmen mampu memberikan dorongan kepada anggota organisasi dan akan membuat organisasi menjadi lebih produktif. Anggota organisasi yang berkomitmen tinggi akan berefek positif pada organisasi. Mereka yang merasa dekat dengan organiasi, akan merasakan bahwa organisasi adalah tempat pemenuhan kebutuhan personal mereka untuk menjalankan kehidupan. Oleh karena itu, mereka akan berbuat dan bekerja dengan sebaik-baiknya, mengerahkan segala kemampuan yang ada, bekerja dengan sungguh-sungguh demi organisasidan dan dibarengi dengan rasa puas terhadap semua yang telah mereka kerjakan (Gibson. Ivancevich, Donnelly, 2009).

Komitmen organisasi yang dimaksudkan oleh peneliti dalam penelitian ini adalah persaan yang dialami oleh setiap dosen dalam menjalankan tugas Tri Dharma Perguruan Tinggi yang berhubungan atas tiga aspek, yaitu mengetahui tujuan yang ingin dicapai oleh perguruan tinggi, bertanggung jawab atas pekerjaan yang telah diembankan, dan bertanggungjawab untuk memberikan loyalitasnya terhadap perguruan tinggi.
Kinerja merupakan sebuah variabel yang sering menjadi sasaran peneliti untuk dikaji dan dianalisis diperbagai instansi, baik instansi pemerintah maupun swasta. Maka, banyak orang ingin mengetahui dengan jelas arti dari kinerja pegawai. Secara epistimologi, kata kinerja (performance) berasal dari kata "to perform" yang memberikan arti: melakukan atau memenuhi /menjalankan sesuatu, bertanggung jawab, dan melaksanakan sesuatu yang diharapkan (Marwan, 2015).

Robert Kreitner dan Angelo Kinicki mengatakan bahwa kinerja tidak akan berkembang tanpa sistem pendukung, seperti orang-orang yang berkemampuan, memiliki keterampilan, dan pengetahuan terhadap pekerjaan yang diselesaikan (Robert Kreitner, 2007).

Kinerja dipengaruhi oleh faktor personal, leadership, tim, sistem dan situasi dari suatu organisasi (Wibowo, 1998). Oleh karena itu kinerja suatu organisasi pada prinsipnya dipengaruhi oleh banyak factor.

\section{METODE PENELITIAN}

Penelitian ini bertujuan membuktikan pengaruh empat variabel eksogenus yaitu budaya, kepemimpinan, kepuasan kerja dan komitmen organisasi terhadap kinerja dosen, sebagai variabel endogenus. Tekhnik pengumpulan data dilakukan dengan metode survey, maka penelitian ini 
termasuk kepada jenis penelitian "explanatory atau comfirmatory" yaitu penelitian yang akan mengkaji hubungan antar variabel dan juga akan melakukan pengujian hipotesis (Singarimbun, M., 1989). Penelitian ini dilaksanakan pada 5 (lima) PTKIN yang ada di Provinsi Aceh yaitu: IAIN Langsa, IAIN Lhokseumawe, STAIN Takengon, UIN Ar-raniry Banda Aceh, dan STAIN Meulaboh. Waktu penelitian dimulai tanggal 1 juni 2016 sampai dengan tangga 1 Juni 2017. Populasi penelitian adalah dosen tetap dan tidak tetap PTKIN provinsi Aceh berjumlah 727 orang. Dengan menggunakan rumus Slovin, maka ditetapkan jumlah sampel 258 orang. Jumlah populasi dan sampel tiap perguruan tinggi disajikan dalam

tabel 1.

Berikut:

Tabel 1. Jumlah Sampel Penelitian Berdasarkan Masing-Masing PTKIN

\begin{tabular}{|c|l|c|}
\hline No. & \multicolumn{1}{|c|}{$\begin{array}{c}\text { Nama } \\
\text { PTKIN }\end{array}$} & Sampel \\
\hline 1. & UIN Ar-raniry Banda Aceh & 173 \\
\hline 2. & IAIN Malikussaleh Lhokseumawe & 30 \\
\hline 3. & IAIN Zawiyah Cot Kala Langsa & 30 \\
\hline 4. & $\begin{array}{l}\text { STAIN Teungku Dirundeng } \\
\text { Meulaboh }\end{array}$ & 2 \\
\hline 5. & STAIN Gaja Puteh Takengon & 23 \\
\hline & J U M L A H & 258 \\
\hline
\end{tabular}

Sumber: Olahan Data Primer, 2016.

Sampel yang ditetapkan pada tabel $1 \mathrm{di}$ atas, merupakan perguruan Tinggi Keagamaan Islam Negeri yang ada di provinsi Aceh. Dimana jumlah sampel tersebut merupakan responden yang akan memberikan jawaban terhadap pertanyaan

Penelitian ini disusun dari instrumen dengan lima variabel yang di dalamnya dilakukan dengan penentuan indikator, nomor butir angket, bentuk dan jumlah item. Untuk memperoleh data yang valid dan reliabel, maka kesemua instrumen dalam penelitian akan diujicoba pada 30 orang dosen IAIN Langsa, Aceh. Analisis ujicoba validitas instrumen akan dilakukan dengan menggunakan rumus Product Moment sebagai berikut:

$$
r_{x y}=\frac{n\left(\sum x_{i} y_{i}\right)-\left(\sum x_{i}\right)\left(y_{i}\right)}{\sqrt{\left[n \cdot \sum \cdot X_{i}^{2}-\left(\sum X_{i}\right)^{2}\right] \cdot\left[n \cdot \sum \cdot Y_{i}^{2}-\left(\sum Y_{i}\right)^{2}\right]}}
$$

Dimana:

$$
\begin{aligned}
r_{x y} & =\text { Koefesien korelasi antara } \mathrm{X} \text { dan } \mathrm{Y} \\
\mathrm{x} & =\text { Skor tiap item } \\
\mathrm{y} & =\text { Skor total tiap item } \\
\mathrm{n} & =\text { Jumlah responden }
\end{aligned}
$$

Selanjutnya diuji reliabilitas instrumen (Keterhandalan) angket menggunakan teknik Alpha Cronbach dengan rumus:

Keterangan:

$$
r_{k}=\left(\frac{k}{k-1}\right)\left(1-\frac{\sum S t^{2}}{S t^{2}}\right)
$$

$$
\begin{aligned}
r_{k} & =\text { reliabilitas instrumen } \\
\sum S t^{2} & =\text { jumlah varians yang valid } \\
\mathrm{k} & =\text { jumlah item } \\
S t^{2} & =\text { varians total }
\end{aligned}
$$

Langkah utama yang harus diupayakan adalah menerjemahkan instrumen sesuai yang dirasakan. 
hipotesis penelitian ke dalam diagram jalur. Selanjutnya variabel-variabel akan digambarkan dalam dalam bentuk model struktural. Akdon menjelaskan bahwa model struktural adalah apabila setiap variabel terikat/endogen $(\mathrm{Y})$ secara unik keadaannya ditentukan oleh seperangkat variabel bebas/eksogen $(\mathrm{X})$.

\section{HASIL DAN PEMBAHASAN}

Berdasarkan hasil analisis data, diterangkan secara bertahap atas besaranbesaran yang akan dianalisis. Hasil perhitungan koefisien jalur antara variabel eksogenius dengan variabel endogenus dirangkum dalam Tabel 2 berikut.

Tabel 2: Rangkuman Hasil Analisis Keberartian Koefisien Jalur antara Variabel Eksogenus dengan Variabel Endogenus

\begin{tabular}{|c|c|c|c|c|}
\hline No. & $\begin{array}{c}\text { Koefisien } \\
\text { Jalur }\end{array}$ & t-hitung & $\begin{array}{l}\text { t-tabel } \\
\alpha 5 \%\end{array}$ & $\begin{array}{c}\text { Ketera } \\
\text { ngan }\end{array}$ \\
\hline 1. & $\rho 31=0,217$ & 3,562 & \multirow{9}{*}{1,65} & $\underset{\text { berarti }}{\text { Jalur }}$ \\
\hline 2. & $\rho 32=0,152$ & 2,467 & & $\begin{array}{c}\text { Jalur } \\
\text { berarti }\end{array}$ \\
\hline 3. & $\rho 41=0,348$ & 5,935 & & $\begin{array}{c}\text { Jalur } \\
\text { berarti }\end{array}$ \\
\hline 4. & $\rho 42=0,216$ & 3,544 & & $\underset{\text { berarti }}{\text { Jalur }}$ \\
\hline 5. & $\rho 43=0,139$ & 2,246 & & $\underset{\text { berarti }}{\text { Jalur }}$ \\
\hline 6. & $\rho 51=0,565$ & 10,946 & & $\begin{array}{c}\text { Jalur } \\
\text { berarti }\end{array}$ \\
\hline 7. & $\rho 52=0,253$ & 4,191 & & $\begin{array}{c}\text { Jalur } \\
\text { berarti }\end{array}$ \\
\hline 8. & $\rho 53=0,316$ & 5,331 & & $\underset{\text { Jerarti }}{\text { Jalur }}$ \\
\hline 9. & $\begin{array}{c}\rho 54= \\
0,377\end{array}$ & 6,518 & & $\underset{\text { berarti }}{\text { Jalur }}$ \\
\hline
\end{tabular}

Setelah dianalisis nilai koefisien jalur, maka dilanjutkan dengan analisis adanya pengaruh langsung dan pengaruh tidak langsung beberapa variabel eksogenus terhadap variabel endogenus. Hasil analisis ini dapat dirangkum dalam Tabel 3 berikut.

Tabel 3: Nilai Koefisien Jalur Pengaruh Langsung, Tidak Langsung, Pengaruh Total dan Korelasi

\begin{tabular}{|c|c|c|c|c|}
\hline \multirow{3}{*}{$\begin{array}{l}\text { Variabel } \\
\text { Eksogenous } \\
\text { terhadap } \\
\text { Variabel } \\
\text { Endogenous }\end{array}$} & \multicolumn{4}{|c|}{ Pengaruh Kausal } \\
\hline & \multirow[t]{2}{*}{$\begin{array}{l}\text { Lang } \\
\text { sung }\end{array}$} & $\begin{array}{l}\text { Tidak } \\
\text { Lang- } \\
\text { sung } \\
\text { Melalui }\end{array}$ & $\begin{array}{l}\text { Tidak } \\
\text { Lang } \\
\text { sung } \\
\text { Melalui }\end{array}$ & \multirow[t]{2}{*}{$\begin{array}{l}\text { Penga } \\
\text { ruh } \\
\text { Total }\end{array}$} \\
\hline & & $\mathrm{X} 3$ & $\mathrm{X} 4$ & \\
\hline $\mathrm{X}_{1}$ ke $\mathrm{X}_{3}$ & 0,21 & - & - & 0,217 \\
\hline $\mathrm{X}_{2}$ ke $\mathrm{X}_{3}$ & 0,15 & - & - & 0,152 \\
\hline $\mathrm{X}_{1}$ ke $\mathrm{X}_{4}$ & 0,34 & 0,011 & - & 0,359 \\
\hline $\mathrm{X}_{2}$ ke $\mathrm{X}_{4}$ & 0,21 & 0,005 & - & 0,221 \\
\hline $\mathrm{X}_{3}$ ke $\mathrm{X}_{4}$ & 0,13 & - & - & 0,139 \\
\hline $\mathrm{X}_{1}$ ke $\mathrm{X}_{5}$ & 0,56 & 0,039 & 0,011 & 0,615 \\
\hline $\mathrm{X}_{2}$ ke $\mathrm{X}_{5}$ & 0,25 & 0,012 & 0,021 & 0,286 \\
\hline $\mathrm{X}_{3}$ ke $\mathrm{X}_{5}$ & 0,31 & - & 0,017 & 0,333 \\
\hline $\mathrm{X}_{4}$ ke $\mathrm{X}_{5}$ & 0,37 & - & - & 0,377 \\
\hline
\end{tabular}

Berdasarkan hasil pengujian hipotesis yang dilakukan menunjukan bahwa semua hipotesis yang diajukan terbukti secara positif dan signifikan, yang memberi arti bahwa terdapat pengaruh antara variabel eksogenus terhadap variabel endogenusnya. Secara bertahap dapat dijelas sebagai berikut:

\section{Pengaruh Budaya lembaga Terhadap Kepuasan kerja Dosen PTKIN di Provinsi Aceh}

Pengaruh langsung budaya lembaga terhadap kepuasan kerja sebesar 0,2172= 0,047, temuan ini menegaskan bahwa budaya lembaga secara langsung menentukan kepuasan kerja sebesar 4,7\%. Penelitian ini membuktikan secara empiris 
bahwa budaya lembaga turut mempengaruhi kepuasan kerja dosen PTKIN di Provinsi Aceh. Jadi semakin kuat budaya lembaga dalam lembaga maka kepuasan kerja dosen akan semakin meningkat.

\section{Pengaruh Langsung Kepemimpinan Terhadap Kepuasan kerja Dosen PTKIN di Provinsi Aceh}

Hasil analisis menemukan bahwa kepemimpinan memberikan pengaruh terhadap kepuasan kerja dengan nilai koefesien 0,1512 atau 2,3\%. Nilai ini memberikan arti, pimoinan dalam menjalankan fungsi manajerialnya akan menentukan perubahan-perubahan kepuasan kerja dosen sebesar 2,3\%. Maka kesuksesan perguruan tinggi dapat juga diupayakan melalui pimpinan untuk mampu menciptakan kepuasan kerja. Jika pimpinan mampu menciptakan kepuasan kerja bagi para dosen di perguruan tinggi dan karyawan, maka akan memberikan efek kepada faktor positif lainnya, seperti kinerja dan komitmen perguruan tinggi. Pendapat Sudjak menjelaskan bahwa kepemimpinan merupakan kekuatan untuk memberikan pengaruh, kemampuan untuk mengarahkan, dan kesanggupan dalam menggerakkan tindakan kerja yang dimiliki seseorang atau kelompok agar tercapainya tujuan yang diharapkan (Abi Sudjak, 1990). Dengan demikian, untuk memperoleh kinerja yang baik, pimpinan haruslah menjalankan roda kepemimpinan yang baik pula. Kepemimpinan harus mampu mempengaruhi berbagai aspek yang mempu meningkatkan kinerja. Kepemimpinan harus mampu menggerakkan semua anggota lembaga di bawah kepemimpinannya dengan segala tuntutan dan harapan yang berefek positif dapat meningkatkan kinerja.

\section{Pengaruh Langsung Budaya lembaga Terhadap Komitmen lembaga Dosen PTKIN di Provinsi Aceh.}

Budaya perguruan tinggi berpengaruh terhadap komitmen PTKIN Aceh sebesar 0,3482 atau $12,1 \%$. Hai ini memberikan arti bahwa budaya perguruan tinggi yang terjadi ikut menentukan kuat atau lemhnya komitmen. Hasil analisis data menunjukan budaya Perguruan Tinggi berpengaruh terhadap komitmen pergurun tinggi sebesar 12,1\%. Budaya lembaga memiliki sejumlah fungsi bagi anggota lembaga dan lembaga. Hal ini dijelaskan Robbins bahwa budaya organisasi akan membedakan antara satu perguruan tinggi dengan perguruan tinggi lainnya, budaya menunjukkan perilaku dan norma terrtentu oleh anggotannya, budaya memperkuat komitmen bersama dari pada individual, budaya mempererat hubungan sosial, budaya dapat mempersatukan organisasi dan merasakan senasib sepenanggungan 
dalam keberhasilan kerja, budaya berperan dalam pemandu keberlangsungan kerja dengan nilai dan norma yang dipahami dalam aktivitas kerja (Abi Sudjak, 1990).

Oleh karena itu, budaya dapat memberikan pengaruh untuk meningkatkan komitmen perguruan tinggi. Karena budaya yang terbentuk merupakan suatu pengakuan bersama dalam bekerja. Nilai dan norma yang terjadi dalam kondisi dan situasi kerja akan diakui oleh semua dosen, dan karyawan dalam menuntaskan pekerjaan..

\section{Pengaruh Langsung Kepemimpinan}

\section{Terhadap Komitmen PTKIN di}

Provinsi Aceh.

Hasil analisis ditemukan bahwa pimpinan PTKIN berpengaruh terhadap komitmen. Artinya, pimpinan perguruan tinggi dapat merubah komitmen perguruan tinggi yang ia pimpin menjadi kuat ataupun lemah. Karena praktek kepemimpinan yang ia jalankan akan memberikan pengaruh kepada komitmen yang dimulai dari setiap perasaan yang dirasakan dosen dalam bekerja. Komitmen yang tinggi akan terlihat dari adanya keinginan para dosen atau karyawan untuk mempertahankan dirinya tetap berada di bawah nawungan perguruan tinggi yang ia ikuti dan menjadi panutannya dalam bekerja.

Dosen atau karyawan yang berkomitmen tinggi selalu berusaha menjaga perguruan tingginya untuk menjadi lembaga terbaik bagi dirinya. Komitmen yang tinggi akan terlihat dari kesetiaan para dosen kepada lembaga, dan mampu menunjukkan sikap-sikap positif dan kerja keras untuk kemajuan perguruan tinggi. Kemampuan kerja keras dan kesetiannya terhadap perguruan tinggi bukan merupakan perilaku yang dimunculkan secara paksaan, tetapi sikap yang telah menjiwai dan terbentuk dalam kepribadiannya selama ia bekerja pada perguruan tinggi.

\section{Pengaruh Langsung Budaya lembaga} Terhadap Kinerja Dosen PTKIN di Provinsi Aceh.

Budaya PTKIN Aceh berpengaruh terhadap kinerja dosen sebesar 0,5652 atau $31,9 \%$. Hal ini menunjukkan bahwa budaya perguruan tinggi menentukan kinerja dosen adalah sebesar 31,9\%. Dengan demikian dosen adalah salah faktor penting untuk meraih visi dan tujuan yang telah direncanakan PTKIN di Aceh. Berdasarkan temuan ini, dapat dijelaskan bahwa budaya perguruan tinggi yang berlangsung dengan baik akan memberikan aktivitas Tridarma Perguruan Tinggi dengan penuh harmonis sesuai dengan harapan. Hal ini sesuai dengan yang apa dituliskan dalam jurnal Assets bahwa budaya organisasi berpengaruh secara positif kepada kinerja dosen. Dimana, 
setiap terdapatnya budaya organisasi memberikan peningkatan kepada kinerja dosen (Awaluddin, 2016).

Pengaruh Langsung Kepemimpinan Terhadap Kinerja Dosen PTKIN di Provinsi Aceh.

Pengaruh kepemimpinan PTKIN terhadap kinerja Dosen sebesar 0,2532 atau 6,4\%. Dengan demikian, pimpinan dalam melaksanakan manajerialnya menentukan tingkat kinerja Dosen sebesar 6,4\%. Pimpinan merupakan orang berpengaruh terhadap orang lain untuk bekerja dalam menyelesaikan pekerjaan. Pimpinan PTKIN harus memiliki kemampuan manajerial untuk memimpin. Pemimpin harus mampu mempengaruhi orang disekelilingnya untuk bekerja dengan baik, memiliki semangat kerja tinggi, motivasi dan komitmen yang tinggi. Tidak semua pemimpin dapat menciptakan suasana tersebut. Bahkan setelah semua kondisi mampu dikondisikan dalam kepemimpinannya, ia juga harus mampu mengevaluasi fluktuasi suasana tersebuat dalam bekerja.

Pengaruh Langsung Kepuasan kerja Terhadap Kinerja Dosen PTKIN di Provinsi Aceh.

Pengaruh langsung kepuasan kerjaterhadapkinerja Dosen sebesar 0,3162 atau 10\%. Dengan demikian, kepuasan kerjayang secara langsung menentukan perubahan-perubahan kinerja dosen adalah sebesar 10\%. Dosen merupakan tenaga edukatif pada perguruan tinggi yang berperan secara kontinyu dalam membentuk kompetensi lulusan. Dosen diharapkan mampu bekerja secara efektif dan efisien dalam semua aspek, baik mengenai pendidikan dan pengajaran, pengabdian kepada masyarakat dan penelitian.

Kinerja dosen di perguruan tinggi merupakan ujung tombak perguruan tinggi dalam pencapaian lembaga. Dosen dituntut untuk mampu meningkatkan kinerja disetiap saat dari waktu ke waktu. Dosen terus diupayakan untuk mampu menunjukkan kinerja yang tinggi.

Pengaruh Langsung Kepuasan kerja Terhadap Kinerja Dosen PTKIN di Provinsi Aceh.

Pengaruh komitmen PTKIN terhadap kinerja Dosen sebesar 0,3772 atau 14,2\%. Dengan demikian, komitmen PTKIN menentukan perubahan-perubahan kinerja dosen adalah sebesar 10\%. Menyelesaikan suatu pekerjaan merupakan kewajiban dosen sebagai misi dalam pencapaian visi dan tujuan pada perguruan tinggi. Pekerjaan yang telah diselesaikan menjadi sebuah hasil yang perlu diukur. Karena pekerjaan yang tepat sesuai tujuan yang diharapkan merupakan bagian dari visi PTKIN di Provinsi Aceh. Persoalan 
kinerja dosen menjadi penting untuk dievaluasi pada setiap perguruan tinggi, agar kinerja yang dihasilkan menjadi maksimal.

\section{KESIMPULAN}

Budaya PTKIN di Provinsi Aceh berkontribusi terhadap kinerja dosen. Beberapa konstribusi yang dimaksud adalah budaya organisasi berpengaruh langsung kepada kepuasan kerja dosen, komitmen, dan kinerja dosen di PTKIN Provinsi Aceh. Selanjutnya, kepemimpinan berpengaruh langsung kepada kepuasan kerja, komitmen dan kinerja dosen di PTKIN Provinsi Aceh. Sementara kepuasan kerja itu sendiri juga dapat mempe-ngaruhi secara langsung terhadap kinerja dosen. Demikian juga halnya bahwa komitmen lembaga dapat mempe-ngaruhi secara langsung kepada kinerja dosen PTKIN Aceh. Dengan demikian, variabel yang berpengaruh dari hasil kajian ini, perlu mendapatkan perhatian lebih serius di kampus PTKIN Aceh dalam upaya meningkatkan kinerja dosen.

\section{REFERENSI}

Abi Sudjak. (1990). Kepemimpinan Manajer. Jakarta: Rajawali.

Adhim, F., \& Hakim, M. N. (2019). Perencanaan Strategi Berbasis Nilai di Lembaga Pendidikan Tinggi. Nidhomul
Haq: Jurnal Manajemen Pendidikan

Islam, $\quad 4(2), \quad 259-279$.

https://doi.org/https://doi.org/10.3

1538/ndh.v4i2.314

Awaluddin, M. (2016). Pengaruh Budaya Organisasi, Kepuasan dan Lingkungan Kerja terhadap Kinerja Dosen UIN Alauddin Makasar. Assets, 6(1), 116-125.

Badani. (2014). Kepemimpinan dan Perilaku Organisas. Bandung: Alfabeta.

Bakri, S., A. F. A. (2014). Pengaruh Internal Service Quality Terhadap Kepuasan Karyawan Pada PT. Bank Riau Kepri. Jurnal Tepak Manajemen Bisnis, 6, 127-139.

Baktirani, F. (2014). Pengaruh Karakteristik Dosen Terhadap Kepuasan Mahasiswa dalam Proses Belajar Mengajar di Institut Agama Islam Negeri (IAIN) Ambon. Jurnal Fikratuna, 6, 10-23.

Colquitt, J.A, Lipine, M. J. W. (2009). Organization Behavior: Improving Performance and Commitment in the Workplace. New York: The McGrawHill Companies.

Dewi, I. S. K., Harlen, \& Sasmita, J. (2015). Pengaruh Budaya Organisasi Dan Pengawasan Terhadap Kinerja 
Melalui Komitmen Karyawan

Frontliner PT Bank Riau Kepri. Jurnal

Tepak Manajemen Bisnis, VII(2), 179_ 191.

Diane Hurber. (1996). Leadership and Nursing Care Management. Philadelphia: WB Saunders Company.

Gibson. Ivancevich, Donnelly, K. (2009). Organization. Behavior, Structure, Processes (Thirteen E). New York: McGraw Hill Companies.

Hakim, M. N. (2016). Implementasi Manajemen Berbasis Sekolah Dalam Mewujudkan Sekolah Islam Unggulan. Nidhomul Haq: Jumal Manajemen Pendidikan Islam, 1(2), 104 114.

https://doi.org/10.31538/NDH.V1I 2.7

Hakim, M. N. (2018). Upaya Kepala Madrasah Dalam Membina Budaya Religius. IMProvement, 5(1), 74-88. https://doi.org/10.21009/Improvem ent.051.07

James A.E. Stoner and Edward Freeman. (1996). Management. New York: Prentice Hall.

Kreitner, R., A. K. (2014). Perilaku Lembaga (Organizational Behavior) (9th ed.). Jakarta: Salemba Empat.
Lunenburg, F.C, dan A. C. O. (2000). Educational Administration, Conceps and Practices (Third Edit). usa: Wadsworth Thomson Learning.

Marudut Sianturi. (2012). Pengaruh Kepemimpinan Transformasional, Komunikasi Interpersonal, pemberdayaan Pegawai, dan Motivasi Terhadap Komitmen Lembaga (Studi Kasus Pada Dinas/Unit Pelaksana Teknis (UPT) Dinas Pendapatan Provinsi Se-Sumatera Utara). UNIMED Medan.

Marwan. (2015). Pengarub Budaya Lembaga, Perilaku Kepemimpinan, Motivasi Berprestasi, Melalui Kepuasan Kerja Terhadap Kinerja Dosen Perguruan Tinggi Swasta Di Provinsi Aceh. UNIMED Medan.

Northouse, P. . (2013). Kepemimpinan (Teori dan Praktik). Jakarta: PT Indeks.

Robbins, S.P., M. C. (2010). Manajemen (sepuluh). Jakarta: Erlangga.

Robbins, S. P. dan M. C. (2007). Manajemen (kedelapan). Jakarta: PT. Indeks.

Robert Kreitner, A. K. (2007). Organizational Behavior. Singapore: The McGraw-Hill Companies.

Salangka R. (2015). Pengarub Self Efficacy, Self Esteem dan Lingkungan Lingkungan 
Nidhomul Haq, Vol 5 No 1 Tahun 2020

Kerja TerhadapKepuasan Kerja Karyawan Pada PT. PLN (PERSERO) Wialyah Suluttenggo. Sulawesi Tenggara.

Singarimbun, M., S. E. (1989). Metode Penelitian Survai. Jakarta: LP3ES.

Siswanto. (2008). Pengantar kinerja. Jakarta: PT Bumi Aksara.

Situmorang, B. (2012). Pengaruh Budaya Organisasi, Kepemimpinan, Komunikasi Interpersonal, dan Kepuasan Kerja Terhadap Komitmen Lembaga Kepala Sekolab (Studi Kasus Pada SMK di Kota Medan). UNIMED.

Tim Dosen Administrasi Pendidikan. (2012). Manajemen Pendidikan. Bandung: Alfabeta.

Wibowo. (1998). Manajemen Kinerja. Jakarta: PT RajaGrafindo.

Yulk, G. (2001). Kepemimpinan Dalam Organisasi (Kelima). Jakarta: PT Indeks. 